\title{
SUSPECTED SURPLUS KILLING OF GREBES BY MINK
}

GARY WOBESER, Canadian Cooperative Wildlife Health Centre, Department of Veterinary Pathology, Western College of Veterinary Medicine, University of Saskatchewan, Saskatoon, SK S7N 5B4

In June 1984, a conservation officer of the Saskatchewan Department of Parks and Renewable Resources requested assistance in investigating mortality in a nesting colony of Western Grebes in Moose Bay on the west side of Doré Lake, SK (54 $42^{\prime} \mathrm{N} ; 107^{\circ} 12^{\prime}$ $W)$. The floating nests were located in a dense stand of bulrushes (Scirpus sp.) about $500 \mathrm{~m}$ from the nearest shoreline. The water was approximately $45-90 \mathrm{~cm}$ deep. Dead birds were first observed on June 10. Acute infectious disease was suspected because some birds were found dead on their nests.

When I visited the site on June 13, ten dead adult birds were found in an area approximately $20 \mathrm{~m}$ in diameter. Three of the ten birds were on their nests and the eggs beneath these birds had not been disturbed. No dead birds were found in the colony outside of this immediate area, nor were any found in a colony in an adjacent bay. To reduce disturbance to the nesting birds, no attempt was made to estimate the total number of live birds or nests in the colony.

Eight grebes (four males, four females) were collected for examination. Seven of these had massive subcutaneous hemorrhage surrounding the back of the skull and the adjacent top of the neck (Fig. 1), and the back of the skull was crushed in four of these birds. There were small puncture wounds, each 1-3 $\mathrm{mm}$ in diameter, in the skin overlying the skull in all seven birds. The eighth bird, a female, was severely emaciated and had no bite wounds. No other evidence of disease was found in these birds. Lung from three of the birds was cultured for disease-causing bacteria; the only organism isolated was Aeromonas hydrophila, a common environmental bacterium found in water.

On July 16, 1998, dead Eared Grebes were found at Eyebrow Lake, Saskatchewan $\left(49^{\circ} 57^{\prime} \mathrm{N} ; 106^{\circ} 12^{\prime} \mathrm{W}\right)$. The portion of the lake where the grebes were found had a large colony of nesting Franklin's Gulls, several colonies of Black-crowned Night-Herons and Eared Grebes, and abundant nesting American Coots, waterfowl and smaller marsh birds. There had been heavy mortality of nestling and fledgling Franklin's Gulls on the lake for several years, and also annual occurrences of botulism that periodically kill thousands of waterfowl on the lake.

Among the animals collected on July 16 were four Eared Grebes found along approximately $200 \mathrm{~m}$ of canoe travel in dense bulrush in an area of the marsh at least $300 \mathrm{~m}$ from the nearest shore. One bird, an adult male with a prominent brood patch, was found immediately adjacent to an intact nest containing two 


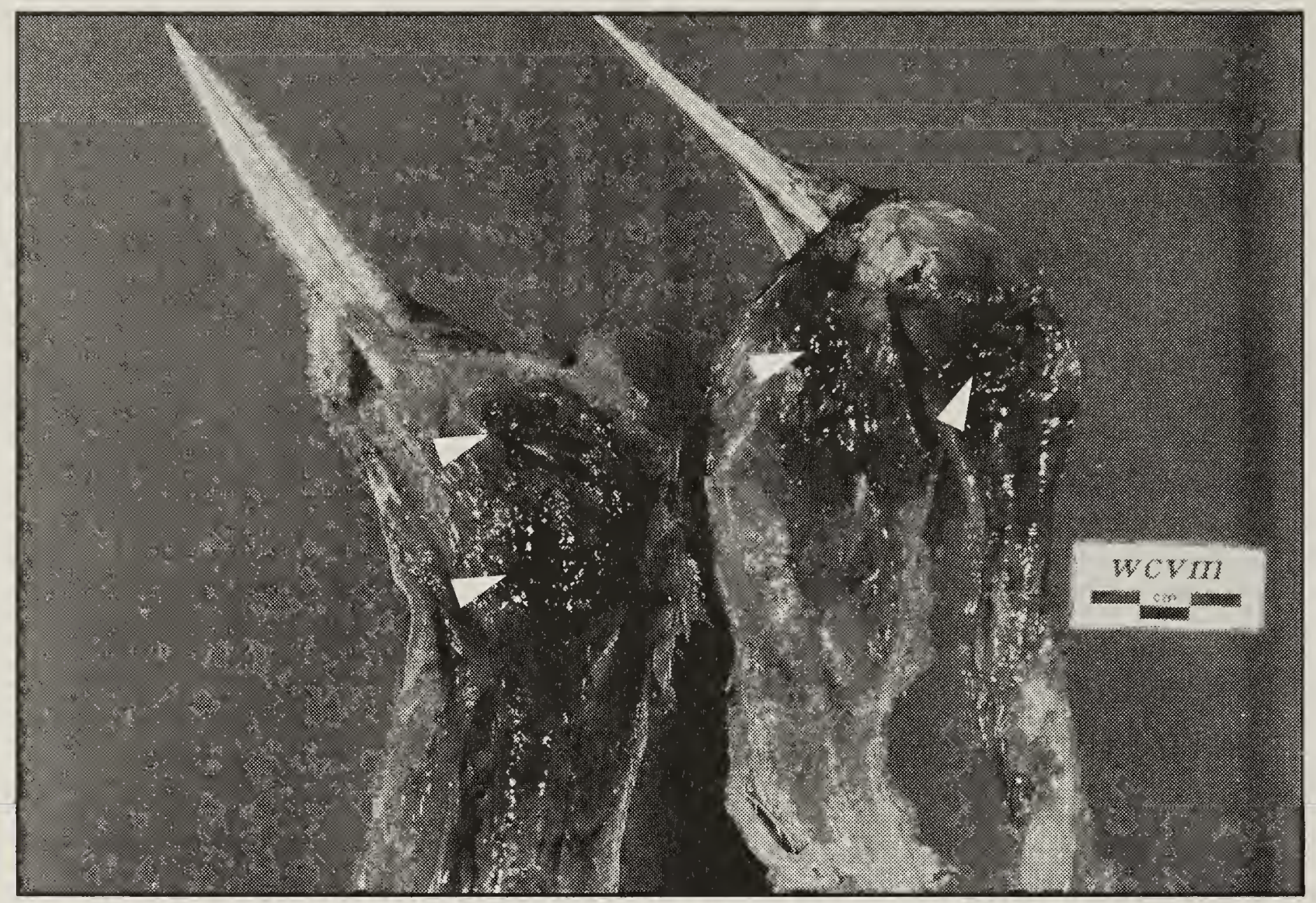

Figure 1. Predator wounds on the head and neck of two Western Grebes found dead at Doré Lake. Skin removed; dark areas are haemorrhage.

eggs. The other birds, all of which were fledglings about $75 \%$ of adult size, were floating in the water without any particular relationship to nests or to each other. All four birds had massive subcutaneous hemorrhage over the back of the skull and upper neck, and the skull was crushed in each bird. As in the Western Grebes, puncture wounds $1-3 \mathrm{~mm}$ in diameter were present in the skin overlying the areas of hemorrhage. In two birds, pairs of puncture wounds, which probably were made by pairs of canine teeth, were spaced approximately $1 \mathrm{~cm}$ apart. No other evidence of disease was detected in any of the birds; the adult was in moderate nutritional condition while all of the fledglings had abundant fat reserves.

In the same vicinity, two dead muskrats were found floating near small islands (about $10 \mathrm{~m}$ in diamter) constructed for nesting waterfowl. One muskrat was a recently emerged baby; the other was a half-grown juvenile. Both also had been killed by bite wounds to the occipital region of the skull.

The location and nature of the wounds in both species of grebe and in the muskrats are typical of those caused by members of the weasel family (mustelids), in which the "method of killing consists of biting the back of the neck or base of the skull, thus severing the spinal cord or crushing the occipital region." 1 Based on the size of the puncture wounds, the spacing between the canine tooth marks, and the location of the birds at some distance from shore, mink were likely the predators in both situations. The only other predator which might be considered would be otter, present at Doré Lake but unlikely to have been present at Eyebrow Lake. Otters have much larger teeth and the spacing between the canine teeth would be greater than that in the wounds found in the grebes. 
The term "surplus killing" was first used by Kruuk to describe situations in which carnivores kill prey far in excess of that which can be consumed at one time. ${ }^{2}$ In this and many other reported instances of surplus killing, a predator is likely presented with an unusual abundance of vulnerable prey under circumstances that have been dubbed the "hen house syndrome". Although grebes were not the only abundant prey species present at these sites, they may have been more vulnerable than species such as Franklin's Gulls because of greater tenacity on the nest.

1. Ben- David, M., S.M. Pelios and V.C. Pellis. 1991. Feeding habits and predatory behaviour in the marbled polecat (Vormela perugusna syriaca): I. Killing methods in relation to prey size and prey behaviour. Behaviour 118:127-143

2. Kruuk, H. 1972. Surplus killing by carnivores. Journal of Zoology (London). 166:233-244

\section{POCKET GOPHER/MOUSE ASSOCIATIONS ON THE MILK RIVER GRASSLANDS}

JIM R. SALT, 464 Nelson Street, Victoria, BC V9A 6P4

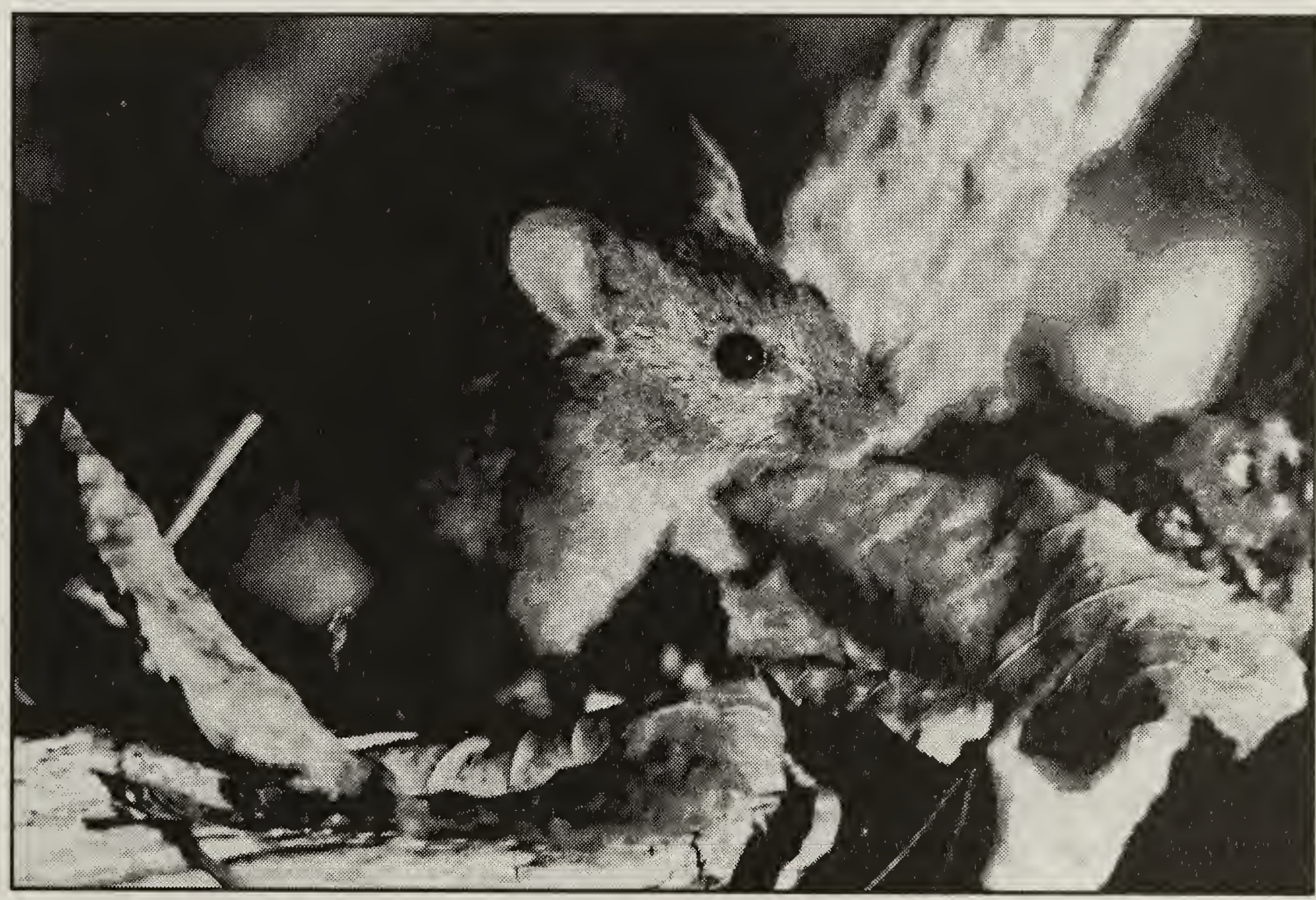

